\title{
Internetes munka a magyar jogban - Tiltás helyett szabályozás?
}

\author{
haknigazdaság - crowdsourcing - applikációs munka - Uber - \\ magyar munkajog
}

\begin{abstract}
Az internetes munkavégzés még szinte nem is létezik Magyarországon, néhány kivételtől eltekintve. ${ }^{1}$ Ezen kivételek közül a legismertebb természetesen Magyarországon is az Uber, amely az ellene irányuló törvénymódosítás hatálybalépésének napján határozatlan időre felfüggesztette magyarországi tevékenységét. Így a „haknigazdasággal”2 kapcsolatos munkajogi kérdések elemzése meglehetősen elvi jellegü lehet csak. Ennek ellenére érdemes felkészülnünk ennek az új, innovatív munkavégzési formának a munkajogi fogadására, mert már nem sokáig tart ez az applikációktól mentes munkaerőpiaci „idill”. A nyugat-európai országokban és például Észtországban is egyre nagyobb szeletet hasít ki a munkaerőpiacból az úgynevezett crowdsourcing és az applikáción keresztül történő munkavégzés (például a Taxify).

Az alábbiakban - az internetes munka fogalmának és alapkérdéseinek ismertetését követően - az Uber kivonulásának történetét elemzem, amely nem a munkajogi kérdésekről szólt, hanem sokkal inkább a taxizással kapcsolatos versenyfeltételekről. Ezt követően az internetes munkavégzők jogviszonyának lehetséges minősítését, majd a munkavállalói jogok kérdéskörét vizsgálom. Arra keresem a választ, hogy mennyiben felkészületlen a magyar munkajog és a jog általában ennek az új munkavégzési formának a fogadására, illetve milyen szabályozási alternatívák kínálkoznak.
\end{abstract}

\section{Az internetes munkavégzés fogalma és alapkérdései}

Napjaink munkajogi szakirodalmának népszerü témája az úgynevezett haknigazdaságba tartozó munkavégzési formák munkajogi problémáinak és szabályozásának elemzése. ${ }^{3} \mathrm{~A}$ haknigazdaságba tartozó munkavégzési formák rendkívül sokszí-

* Dr. Gyulavári Tamás egyetemi tanár, Pázmány Péter Katolikus Egyetem Jog- és Államtudományi Kar Munkajogi Tanszék, gyulavari.tamas@jak.ppke.hu.

Ennek okairól egyáltalán nem állnak rendelkezésre kutatások.

2 A tanulmányban vizsgált jelenség elnevezésére számos kifejezést használnak a szakirodalomban (például gig economy, sharing economy), amelyek közül a szerző a gig economy magyar tükörfordítását használja.

3 Lásd például: PrASsL, Jeremias-RISAK, Martin: Uber, Taskrabbit, \& co: platforms as employers? Rethinking the legal analysis of crowdwork. Comparative Labor Law and Policy Journal, 2016/3, 619-651; DAvIDOV, 
nủek, de közös elemük az internet használata az ellenértékért történő munkavégzés során. Az internetes munkavégzés egy rendkívül színes, szerteágazó jelenség, amelyet éppen ebből eredően igen nehéz tipizálni. Ennek ellenére a nemzetközi irodalomban szokásos megkülönböztetés szerint az interneten alapuló munkavégzési formáknak két fő típusa van: a crowdsourcing és az applikáción alapuló munkavégzés.

A crowdsourcing során egy szervezet a hagyományos esetben belsőleg, saját dolgozók vagy alvállalkozók által elvégzett feladatokat a szervezettől független személyek nagy csoportjának szervezi ki, jellemzően online formában. ${ }^{4}$ A crowdsourcing platform egy megoldandó problémát tesz közzé az interneten, ösztönzőkkel együtt, lehetővé téve a szakértelemmel rendelkező emberek számára, hogy a probléma megoldásában hasznosítsák a tudásukat. ${ }^{5}$ A crowdsourcing tehát a digitális foglalkoztatás olyan új formája, amelynél meghatározatlan számú személy digitális terméket állít elő egy nyílt ajánlatra válaszként. ${ }^{6}$ A crowdsourcing szót John Howe alkotta meg 2006-ban egy internetes írásában a Wired internetes újságban a crowd (tömeg) és az outsourcing (kiszervezés) szavak összevonásával. ${ }^{7}$ Míg az outsourcing során a munkát harmadik személynek, társaságnak, intézménynek, addig a crowdsourcing esetében az ismeretlen nagyságú tömegnek szervezik ki az interneten közzétett nyílt felhívással (ajánlattal). ${ }^{8}$

Az internetes munka másik típusa az online applikáción keresztül történik a fogyasztók erre vonatkozó, a honlapon kifejezett igénye szerint (work on demand via app). Ebben az esetkörben olyan hagyományos, fizikai szolgáltatásokról van szó, mint például a taxizás (például Uber), takarítás és javítás (például Helpling), irodai

Guy: The Status of Uber Drivers: A Purposive Approach, 2017. http://www.labourlawresearch.net/ sites/ default/files/papers/The status of Uber drivers A purposive approach copy.pdf; DE STEFANO, Valerio: The rise of the "just-in-time workforce": on-demand work, crowd work and labour protection in the "gig-economy". Comparative Labor Law and Policy Journal, 2016/3, 471-503; FINKIN, Matthew: Beclouded Work in Historical Perspective. Comparative Labor Law and Policy Journal, 2016/3, 603-618; KovÁcs Erika: Regulatory Techniques for 'Virtual Workers.' Hungarian Labour Law E-Journal, 2017/2, 1-15; SCHIEK, Dagmar-GIDEON Andrea: Outsmarting the gig-economy through collective bargaining - EU competition law as a barrier? International Review of Law Computers \& Technology, 2018/3, 1-20, https://www.researchgate.net/ publication/324449617_Outsmarting_the_gigeconomy_through_collective_bargaining_-_EU_competition_ law_as_a_barrier_to_smart_cities; Sмітн, Rebecca-LeBERSTEIN, Sarah: Rights on Demand: Ensuring Workplace Standards and Worker Security in the On-Demand Economy. New York, National Employment Law Project, 2015, http://www.nelp.org/content/uploads/Rights-On-Demand-Report.pdf; FLoRISson, Rebecca-MANDL, Irene: Digital age Platform work: Types and implications for work and employment Literature review. Eurofound, Publications Office of the European Union, Luxembourg 1. 2018; CHERRY, Miriam-Poster, Winifred: Crowdwork, Corporate Social Responsibility, and Fair Labor Practices. Saint Louis University Legal Studies Research Paper, 2016/8. https://ssrn.com/abstract=2777201 (2018. 08. 04.).

4 https://hu.wikipedia.org/wiki/Crowdsourcing (2018. 08. 04.).

5 Rouse, Anne C.: A Preliminary Taxonomy of Crowdsourcing. AIS Electronic Library, 2010, 3. http://aisel. aisnet.org/cgi/viewcontent.cgi?article=1031\&context=acis2010 (2018. 08. 03.).

6 „Crowdsourcing Code of Conduct”. http://crowdsourcing-code.com/ (2018. 07. 06.).

7 Leimeister, Jan Marco-Zogaj, Shkodran-Durward, David: New Forms of Employment and IT - Crowdsourcing. In: Blainpain Roger-Hendrickx Frederic (eds.): New Forms of Employment in Europe. (Bulletin of Comparative Labour Relations, 2016/94.) Wolters Kluwer, Alphen aan den Rijn, 2016, 24.

8 LeIMEISTER-Zogaj-Durward: i. m., 26. 
munkák, könyvelés (például Upwork). ${ }^{9}$ Online applikáció segítségével lehet hívni munkavégzőt, akit az applikáció választ ki és közvetít a megrendelőnek. Az ügyfél általában a szolgáltató applikációnak fizet, amely a platform által meghatározott közvetítői díj levonása után átutalja a munkadíjat (lényegében a munkabért) a munkavégzőnek. A digitális platform tehát megszabja a honlapon az árat, a minimális minőségi előírásokat, kiválasztja és szervezi a szükséges munkaerőt. ${ }^{10}$

Az internetes munkavégzésre irányuló jogviszony munkajogi minősítéséből következik az, hogy milyen munkajogi szabályokat kell, ha egyáltalán kell, alkalmazni az ilyen módon munkát végzők jogviszonyára. A kérdés persze úgy egyszerüsíthető le, hogy munkaviszonynak minősül-e az internetes munkavégzők jogviszonya. De még ha a válaszunk nemleges is erre a kérdésre, akkor is számos más szabályozási és minősítési alternatíva kínálkozik valamilyen szintű munkajogi védelem biztosítására.

A jogviszony minősítése azonban nemcsak a szakirodalomban, hanem a gyakorlatban is komoly érdeklődést váltott ki az elmúlt években. Maguk a platformok is élénken figyelik, és lehetőségük szerint befolyásolják is ennek a minősítő munkának az alakulását. A minősítés végső terepe természetesen a bíróság, amely kimondja az utolsó szót az ilyen jogvitákban. Az amerikai és európai uniós nemzeti bíróságok, valamint az Európai Bíróság is hozott már a témában ítéleteket. Ezek a bírói fórumok nem feltétlenül ugyanazokat a kérdéseket vizsgálják, és persze korántsem ugyanarra az eredményre jutnak.

A jogi minősítés már azért is érdekes, mert meghatározza az alkalmazandó munkajogi szabályok körét. A lényegi kérdés tehát nem is annyira maga a minősítés, hanem sokkal inkább az, hogy pontosan milyen szabályokat kell alkalmazni az internetes munkavégzőkre, valamint milyen további szabályokra volna szükség. Az egyik további kérdés itt az, hogy mely kérdések szabályozása kíván meg a jogviszony sajátosságai folytán különös, eltérő szabályokat. E körben olyan témakörök említhetők meg, mint az értékelés átláthatósága, hordozhatósága és következményei, különösen az inaktiválás, másként a jogviszony megszüntetése. ${ }^{11}$

A jogokkal kapcsolatos másik kérdés pedig az, hogy mely munkavállalói jogok kiterjesztése volna indokolt. A kiterjesztés egyik módja lehet az érintett jog univerzalitása, vagyis minden munkavégző számára történő garantálása, tekintet nélkül a munkavégzésre irányuló konkrét jogviszonyra. Az egyes alapvető jogok nemcsak a munkavállalókat illetnék meg, hanem lényegében mindenkit, aki munkát végez (például kollektív alku, minimálbér, diszkrimináció tilalma).

Az alábbiakban az internetes munka magyar vonatkozásait elemzem. Természetesen itt is a jogviszony minősítése a kiinduló kérdés, és ezt követi majd egyes munkavállalói jogok elemzése az internetes munka szemüvegén keresztül. Mivel a magyar gyakorlatban szinte még nem is létezik ez a munkavégzési forma, ezért itt elsődlegesen elméleti jellegủ gondolatkísérletre vállalkozom majd. Összességében arra vállalkozom, hogy felmérjem a magyar jog felkészültségét ezen a területen, és javaslatokat is tegyek a magyar munkajog fejlesztésére.

PRASSL-RISAK: i. m., 623.

10 De Stefano: i. m., 471-472.

11 „Firing by the algorythm.” Kovács: i. m., 13. 


\section{A haknigazdaság magyar kezdetei: az Uber tündöklése és bukása}

A digitális platformon keresztül történő munkavégzés ma még csak nyomokban létezik Magyarországon, hiszen egy-két olyan honlap müködik, amelyen keresztül munkát lehet végezni (például Taxify). ${ }^{12}$ Ezek közül a legismertebb kétségtelenül a taxizással foglalkozó Uber volt, amely csak 2014-ben kezdte meg a tevékenységét Magyarországon,,$^{13}$ és kivonulásakor már 1200 sofört „foglalkoztatott”. ${ }^{14} \mathrm{Az}$ Uber azonban 2016-ban kivonult Magyarországról ${ }^{15}$ a taxizásra vonatkozó szabályozás - kifejezetten az Ubert célzó - módosítása miatt. Működésüket határozatlan időre függesztették fel, de nem zárták ki, hogy ha pozitív változást tapasztalnak, visszatérhetnek. ${ }^{16}$

Az engedély nélkül, személygépkocsival végzett személyszállító szolgáltatáshoz kapcsolódó jogkövetkezményekröl szóló kormányzati törvényjavaslat ${ }^{17}$ elfogadása ${ }^{18}$ óta ideiglenesen, legfeljebb 365 napig blokkolni lehet ugyanis azokat az internetes oldalakat, amelyek jogellenesen müködő taxiszolgáltatást kínálnak. A közlekedési hatóság rendeli el az ilyen szolgáltatást biztosító alkalmazásoknak, illetve a szolgáltatást népszerüsítő weboldalaknak az ideiglenes hozzáférhetetlenné tételét. ${ }^{19}$ A tiltás akkor rendelhető el, ha a taxiszolgáltatást szervező vagy közvetítő nem felel meg a kormányrendeletben ${ }^{20}$ meghatározott diszpécserszolgálati követelményeknek, ${ }^{21}$ és ezen engedély hiánya miatt a hatóság bírságot szabott ki, a megbírságolt pedig tovább folytatja ezt a tevékenységet. ${ }^{22}$

A szabályozás tehát más, nem taxizással foglalkozó digitális platformokat nem érint. Ugyanígy nem vonatkozik a tiltás azokra a weboldalakra és applikációkra,

12 https://taxify.eu/hu/.

13 Budapestre tart az Uber, a taxisok rémálma. 444.hu, 2014. 06. 13. https://444.hu/2014/06/13/budapesten-isvege-lehet-a-taxisok-egyeduralmanak (2018. 09. 27.).

14 Kivonul az Uber Magyarországról. Index, 2016. 07. 13. https://index.hu/gazdasag/2016/07/13/kicsinaltak_ az_ubert_kivonul_magyarorszagrol_a_ceg/ (2018. 09. 27.).

15 A tiltó törvényi szabályozás hatálybalépésének napján, azaz 2016. július 24-én délben fejezte be tevékenységét Magyarország területén az Uber. „Nagyon nehezen hoztuk meg ezt a döntést, de kénytelenek voltunk, mert a július 24-én életbe lépő törvény miatt az uberező soförök elveszíthetik a jogosítványukat vagy az autójuk rendszámát, annak ellenére, hogy minden engedéllyel rendelkeznek és adót fizetnek. Ezek olyan kockázatok, amiknek az Uber egyetlen magyar alvállalkozó sofört sem szeretne kitenni." Kivonul az Uber Magyarországról, i. m.

16 Kivonul az Uber Magyarországról, i. m.

17 T/10529. számú törvényjavaslat az engedély nélkül, személygépkocsival végzett személyszállító szolgáltatáshoz kapcsolódó jogkövetkezményekröl.

18 2016. június 12-én fogadták el a törvényt, amely 2016. július 24-én lépett hatályba.

19 Ez a megoldás lényegét tekintve hasonlít a francia jogszabályra, amely azonban szigorúbb büntetőjogi szankciókkal, így szabadságvesztéssel, pénzbírsággal, szakmai vagy társadalmi tevékenységtől való eltiltással, a vállalkozás telephelyeinek bezárásával, valamint elkobzással rendeli büntetni az ügyfelek olyan személyekkel való összekapcsolására létrehozott rendszer megszervezését, akik engedély nélkül közúti személyszállítási szolgáltatásokat nyújtanak. C-320/16 Nabil Bensalem v Uber France SAS ügy (2018), Para 16. ECLI:EU:C:2018:221.

20 176/2015. (VII. 7.) Korm. rendelet a személygépkocsival díj ellenében végzett közúti személyszállításról.

21 176/2015. (VII. 7.) Korm. rendelet, 16-17. §.

22 2016. évi LXXV. törvény az engedély nélkül, személygépkocsival végzett személyszállitó szolgáltatáshoz kapcsolódó jogkövetkezményekröl. 
amelyek engedéllyel végeznek személyszállító szolgáltatást. Amint látható, az Uber betiltása egyáltalán nem a foglalkoztatási szabályokkal, vagyis a munkajoggal függött össze. A szabályozás változásával azt kívánták kikényszeríteni, hogy az Uber ne a taxizásra vonatkozó egyre szigorúbb szabályok és az adózási szabályok kikerüléséből szerezzen versenyelönyt a hagyományos taxikkal és taxitársaságokkal szemben. ${ }^{23}$

Látszólag a diszpécserszolgálat engedélyeztetésére kötelezték csak az Ubert. De a kormányrendelet szerint „a diszpécserszolgálat az utazási igényt csak a személytaxi-szolgáltatás nyújtására jogosult személytaxi vezető részére közvetítheti és szervezheti. Diszpécserszolgálattal utazásközvetítő, vagy utazásszervező szolgáltatásra szerződés csak abban az esetben köthető, ha a szerződés alapján a személyszállító szolgáltatást személytaxi-szolgáltatás nyújtására jogosult vállalkozás teljesíti." Tehát a nagy változás az volt, hogy a taxisokra vonatkozó összes kormányrendeleti szabály betartására kötelezték az Ubert és soförjeit. Így lényegében elveszett az összes költségbeli versenyelöny, amelyet a taxisokhoz képest korábban élveztek az uberesek.

Egy budapesti taxis a döntés után hosszan sorolta a kiadásait, „öbbek között a 100-150 ezer forintos flottadijat, a sárgítást, a vizsgákat, és szerinte úgy igazságos, ha ez alól egyetlen fuvarozó sem mentesül”. ${ }^{24} \mathrm{~A}$ kormány szerint „a változtatás célja a szabályosan müködő, adót fizető magyar vállalkozók védelme volt a tudatosan szabálykerülő magatartások visszaszorításával". ${ }^{25} \mathrm{~A}$ törvényt előterjesztő Nemzeti Fejlesztési Minisztérium közleménye a következöképpen foglalta össze a kormány álláspontját: „A kormány támogatja az innovatív megoldásokat, de ahhoz ragaszkodik, hogy a személyszállitásban résztvevő piaci szereplök egyenlő feltételek mentén, törvényesen müködjenek és adót fizessenek. Az Uber adóelkerüléssel és a magyar jogszabályok semmibevételével, engedély nélkül végzett személyszállitó tevékenységet, és így tett szert versenyelönyre, emiatt más országokban be is tiltották vagy korlátozzák tevékenységét." ${ }^{26}$

\section{A haknigazdaság foglalkoztatási jogviszonyai: munkaviszony vagy önfoglalkoztatás?}

A taxizással kapcsolatos új szabályozás munkajogi vonatkozásainak hiányát jelzi, hogy rendszerint a hagyományos taxitársaságok sem munkaviszonyban foglalkoztatják a velük jogviszonyban álló taxisokat, hanem polgári jogviszonyban (megbízási szerződéssel), önálló vállalkozóként. Ugyanakkor az is tény, hogy az uberezők mind

23 Éppen ezért a 2016. évi LXXV. törvény a személyszállítási szolgáltatásokról szóló 2012. évi XLI. törvényt módosította.

24 Uber-betiltás: Magyarország visszalépett az időben. 24.hu, 2016. 06. 13. https://24.hu/belfold/2016/06/13/ uber-betiltas-magyarorszag-visszalepett-az-idoben/ (2018. 09. 27.).

25 Hatékonyságot ígér a kormány, ezért mentek neki az Ubernek. 24.hu, 2016. 06. 13. https://24.hu/ belfold/2016/06/13/hatekonysagot-iger-a-kormany-ezert-mentek-neki-az-ubernek/ (2018. 09. 27.).

26 Kivonul az Uber Magyarországról. 24.hu, 2016. 07. 13. https://24.hu/kozelet/2016/07/13/breking-kivonul-azuber/ (2018. 09. 27.). 
megbízási szerződéssel dolgoztak, így nem vonatkozott rájuk semmiféle jogi védelem, ezért teljesen kiszolgáltatottak voltak a „vállalat” felé. ${ }^{27}$ Versenyelőny a munkajog kikerüléséből tehát azért nem származott, mert a taxisok általában kikerülik a munkaviszonyt, legyen az Uber-soför vagy bármilyen más taxis vállalkozásnak dolgozó.

Bár semmiféle nyilvános adat nem áll rendelkezésre erre vonatkozóan, de a még ma is aktív, lényegében az Uber helyére lépő Taxify feltételeiből ítélve ${ }^{28}$ a soförök itt is elsősorban egyéni vállalkozóként vagy cégen keresztül számláznak, de rendszerint megbízási jogviszonyban állnak a „vállalattal” (platformmal). Érdemes idézni a Taxify sofőrszabályzatából: „A Taxify [...] tisztában van azzal, hogy egyéni vállalkozó partnereinek a magasszintü utaskiszolgálás mellett a tevékenységével együtt járó adminisztrációs kötelezettségeinek is eleget kell tenniük. Ezért a Taxify mindazon egyéni vállalkozó partnerének, aki legalább heti 90 utat teljesít, 10000 Ft összeget a legközelebbi elszámoláskor jóváír." 29

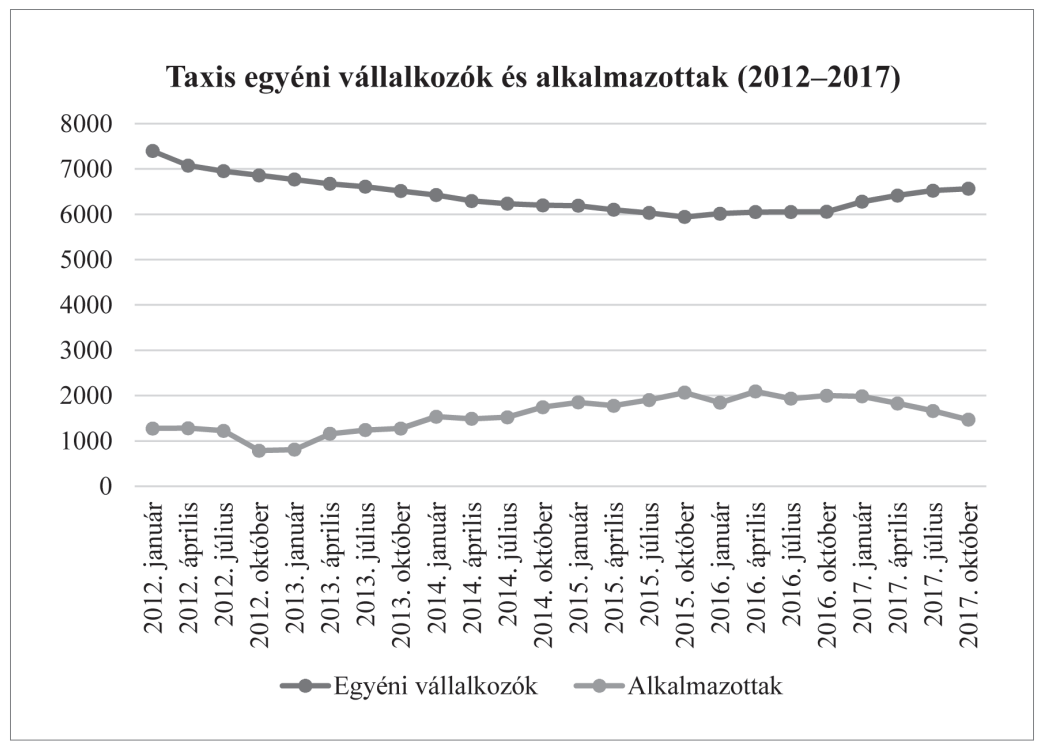

Forrás: Index (az Opten céginformációi alapján), 2017. 12. 08.30

27 Kivonul az Uber Magyarországról, i. m.

28 Szemelvények a Taxify használati útmutatóból: „Te döntöd el, hogy mikor és mennyit vezetsz... Rugalmas, egyedi időbeosztást alakithatsz ki magadnak, nem lesz fix munkaidőd... Nálunk nincs fix tagdíj, se csatlakozási dij, így mellékállásban is kifizetődően vezethetsz... Teljesítményarányos jutalékrendszerrel dolgozunk... A kifizetéseket mindig heti rendszerességgel utaljuk... Utcáról beülős fuvarokat is tudsz teljesíteni a Taxify neve alatt... Hozzánk akkor is jöhetsz, ha nem rendelkezel saját autóval, partnereinken keresztül akár taxi (tartós) bérletre is van lehetöséged."

29 A Taxify soförszabályzata. https://intercom.help/b4nyh34o/taxify-hungary/soforoknek/sofor-szabalyzat (2018. 09. 27.).

30 Egyre több az egyéni vállalkozó taxis. Index, 2017. 12. 08. https://index.hu/gazdasag/2017/12/08/egyre_ tobb_az_egyeni_vallalkozo_taxis/ (2018.09. 27.). 
Amint az a fenti ábrán látható, az elmúlt években enyhén nőtt a taxisok között a munkavállalók (alkalmazottak) és csökkent az egyéni vállalkozók (önfoglalkoztatók) száma, de ez a trend 2017-ben gyökeresen megfordult. 2017-ben ugyanis mintegy harmadával esett a taxitársaságokhoz bejelentett alkalmazottak száma, míg ugyanezen időszak alatt 5 százalékkal nőtt a taxis egyéni vállalkozók száma. Ez a trend ellentétes a 2012-2016 közötti időszakéval, és a 2017-es fordulat vélhetően erősen kötődik az online pénztárgép bevezetéséhez. ${ }^{31}$

Az önálló vállalkozó taxisok tehát általában különféle adózási formát használnak (például kata), rendszeresen egyéni vállalkozóként vagy cégen keresztül számlázva. Kérdéses persze, hogy a taxitársaságoknak dolgozó taxisok jogviszonya munkaviszonynak minősülne-e egy munkaügyi perben, vagy inkább polgári jogviszonynak a jogviszony minősítő jegyei alapján. Kétségtelen ugyanis, hogy a személyi függőség, a munkavállaló rendelkezésre állási kötelezettsége és a munkáltató foglalkoztatási kötelezettsége általában nem igazán jellemzi a munkavégzésüket. Így a munkaviszonyra oly jellemző személyi függőség, alárendeltség, hierarchia nem állapítható meg az ő jogviszonyukra. ${ }^{32}$ Ezzel szemben gazdaságilag kétséget kizáróan függenek a taxivállalattól, hiszen általában csak tőle kapnak és kaphatnak fuvart, így megszünik a jövedelmük, ha véget ér a „polgári” jogviszonyuk a taxivállalattal.

A fentiekből az is következik, hogy a foglalkoztatásra irányuló jogviszony minősítése szempontjából szinte elhanyagolhatók a különbségek a hagyományos taxisok (például Budapest Taxi) és az applikáción keresztül munkát végző Taxify/Uber taxisok között. Mindezek alapján a taxisoförök (beleértve az applikáción keresztül dolgozókat) jogviszonya nem tisztán munkaviszony, hiszen nem állapítható meg egyértelműen az alapvető minősítő jegynek tekinthető személyi függés, alárendeltség, hierarchia.

Különösen vitatható a munkavállaló rendelkezésre állási és a munkáltató foglalkoztatási kötelezettségének megléte. A taxis szabadon dönt, hogy mikor dolgozik, részben pedig szabadon arról, hogy melyik felkínált munkát vállalja el. A munkáltató viszont egyáltalán nem köteles munkát felajánlani, és indokolás nélkül inaktiválhatja is a munkavégzőt, vagy felmondhat neki a polgári jog szabályai szerint. A munkaeszközt általában a munkavégző biztosítja, az az ő tulajdona, és nincs sem munkarend, sem munkaidő-beosztás.

Figyelemre méltó, hogy a munka törvénykönyvének munkaviszony-meghatározása kiemelt jelentőséget tulajdonít a munkáltató foglalkoztatási és a munkavállaló rendelkezésre állási kötelezettségének. ${ }^{33} \mathrm{Az}$ angol munkajogban a kölcsönös kötelezettségvállalás vizsgálata az egyik legvitatottabb minősítő teszt (mutuality of obligations), mivel kizárja az új munkavégzési formákat, így például az internetes munkavégzést a munkajogi védelemből.

31 Egyre több az egyéni vállalkozó taxis, i. m.

32 Lásd például a Taxify sofőrszabályzatában: „Kizárólag a Soför belátásán múlik annak eldöntése, hogy az Igények fogadása szempontjából rendelkezésre áll-e. Ha azonban beleegyezően az lgények fogadása szempontjából való elérhetősége mellett dönt, köteles a jelen Szabályzat feltételeit betartani, és az Applikáción keresztül beérkező fuvarigények $70 \%$-át köteles elfogadni... A Soför tudomásul veszi, hogy a rendelkezésre állás ideje alatt akár az Alkalmazáson, akár más módon beérkező lgényeket lehetőség szerint el kell fogadnia a jelen Szabályzat szerint."

33 2012. évi I. törvény a munka törvénykönyvéről (Mt.) 42. §. 
Ugyanakkor a jogviszony számos más elemében hasonlít a munkaviszonyhoz, így különösen jellemzi a gazdasági függés, a személyes munkavégzési kötelezettség, ${ }^{34}$ a munkabérhez hasonló rendszeres dijjazás, rendszeres és folyamatos munkavégzés. ${ }^{35}$ Ezek közül ki kell emelni, hogy az internetes munkavégzö függ a platformtól, amely a jó értékelést szerzőket igyekszik hosszú távon magához láncolni, hiszen szüksége van a munkájára ${ }^{36} \mathrm{~A}$ munkajogi védelem céljából kiindulva kijelenthető, hogy ezen munkavégzők esetében szükséges és indokolt a munkajogi védelem bizonyos szintjének biztosítása.

A magyar minősítésre is hatással lehet az Európai Bizottság haknigazdasággal (collaborative economy) kapcsolatos közleménye, amely többek között állást foglal az internetes munkavégzés minősítésével kapcsolatban. A Bizottság szerint ${ }^{37} \mathrm{a}$ munkaviszony minősítő jegyei közül különösen az alábbi háromnak van kiemelkedő jelentősége az internetes munkavégzők jogviszonyának minősítése során: az alárendelt kapcsolat megléte, a munka jellege és természete szerint valódi gazdasági tevékenység, valamint a díjazás (ellenérték) fizetése. Amint erre korábban utaltam, ezek közül különösen az első, az alárendeltség, függés és hierarchikus viszony megléte vitatható.

A magyar taxisok státusza (az applikációs és normál taxisoké egyaránt) - álláspontom szerint - a gazdaságilag függő munkavégző, másként a munkavállaló jogállásához hasonló személyhez hasonlít leginkább. Ez a munkajogi kategória azonban nem létezik még a magyar munkajogban, a 2012-ben, az új munka törvénykönyve elökészítése során született, majd végül elvetett javaslat ellenére. ${ }^{38}$

A fenti elemzésböl viszont logikusan az következik, hogy a magyar munkajog teljes mértékben felkészületlen az internetes munkavégzési formák fogadására, mivel rendkívül merev rendszerében csak a mindent vagy semmit elve alapján közelít ezekhez a munkavégzőkhöz (internetes munkavégzők, de hagyományos taxisoförök is). A magyar munkajog klasszikus bináris modelljében az internetes platformnak dolgozó munkavégzők vagy munkavállalónak minősülnek, és akkor minden munkajogi védelmet megkapnak az Mt. szerint, vagy pedig önfoglalkoztatók lesznek, mindennemü védelem nélkül a Ptk. hatályában.

A magyar munkajog tehát a harmadik kategóriát sem ismeri, külön jogviszony sem alkalmazható rájuk, és különös szabályok sincsenek az Mt.-ben arra az esetre, ha a munkaügyi bíróság munkavállalónak minősítené őket. Így viszont a munkaviszonyként történő minősítés sem jó megoldás, mert speciális szabályok hiányában

34 Az applikáció személyre szól.

35 Hasonló elemeket emel ki a minősítésnél RÁcz lldikó: Munkavállaló vagy nem munkavállaló? A gig-economy föbb munkajogi dilemmái. Pécsi Munkajogi Közlemények, 2017/1, 85.

36 RISAK, Martin: Crowdworking. Towards a 'New' Form of Employment. In: Blainpain, Roger-Hendrickx, Frederic (eds.): New Forms of Employment in Europe. (Bulletin of Comparative Labour Relations, 2016/94.) Wolters Kluwer, Alphen aan den Rijn, 2016, 96.

37 „Effective and genuine” - „tényleges és valós” gazdasági tevékenység. A közösségi gazdaságra vonatkozó európai menetrend - A Bizottság Közleménye az Európai Parlamentnek, a Tanácsnak, az Európai Gazdasági és Szociális Bizottságnak és a Régiók Bizottságának. COM(2016) 356 final.

38 A 2012-es javaslat tartalmát és történetét részletesen lásd GYULAVÁRı Tamás: A gazdaságilag függő munkavégzés szabályozása: kényszer vagy lehetőség? Magyar Munkajog, 2014/1, 1-25. http://hllj.hu/letolt/2014_1/01.pdf (2018. 10. 17.). 
nem alkalmazhatók mechanikusan a tipikus vagy akár az atipikus munkaviszonyokra (például munkaerő-kölcsönzésre, távmunkára) vonatkozó szabályok.

Az egyik óhatatlanul felmerülö kérdés természetesen az, hogy megoldaná-e a fenti problémákat, ha a magyar munkajogban is szabályozásra kerülne a harmadik munkajogi kategória: a gazdaságilag függő munkavégző, másként a munkavállalóhoz hasonló jogállású személy. A harmadik kategória valóban a megoldás? Álláspontom szerint ez a munkajog hatályára vonatkozó, jelentős és szükséges reform csak részben oldaná meg az internetes munkavégzésből eredő problémákat. Az internetes munkavégzők csoportja ugyanis sokszínű. Vannak közöttük egyértelműen munkavállalónak minősülők, gazdaságilag függő munkavégzők és tisztán önfoglalkoztatók egyaránt. A harmadik kategória szabályozása tehát az érintettek csak egy részének adna valódi megoldást, ráadásul az ilyen jogi státuszban munkát végzők csak nagyon csökkentett védelemben részesülnének. Továbbá vannak olyan munkavállalói jogok, amelyek az internetes munkavégzés sajátosságaiból eredően speciális szabályozást igényelnek. Az alábbiakban áttekintem néhány ilyen alapvető jog jelenlegi érvényesülésével kapcsolatban a feltételezhető problémákat.

\section{Az eltérő szabályozás dilemmái}

Az internetes munkavégzés és azon belül az applikáción alapuló munkavégzés egyik megkülönböztető sajátossága a munkavégző munkájának online értékelése és az abból eredő hátrányos következmények alkalmazása. Az értékelésre vonatkozóan a magyar munkajogban nincs olyan szabály, amely alkalmazható volna. Ebből eredően semmi nem garantálja, hogy az online értékelés átlátható, vitatható legyen. Továbbá az értékelés hordozhatóságát sem garantálja munkajogi szabály. Mindezek olyan alapvető jogok, amelyeket különös rendelkezéssel kellene garantálni az internetes munkavégzők számára, akár a munka törvénykönyvében, ${ }^{39}$ akár azon kívül, más jogszabályban.

Az online értékelésnek alapvetően kétféle következménye lehet: egyfelől hátrányos jogkövetkezmény alkalmazása, másfelöl a jogviszony megszüntetése (inaktiválás, kizárás). Ezekre jó példa a Taxify sofőrszabályzata, amely táblázatban részletesen meghatározza a „szankciók” (figyelmeztetés, pénzbírság, kizárás) mértékét a „szabálysértés típusa” és súlya szerint. ${ }^{40} \mathrm{Az}$ Mt. szerint hátrányos jogkövetkezmény, másként fegyelmi büntetés alkalmazására csak kollektív szerződés, vagy ennek hiányában munkaszerződés rendelkezése alapján van lehetőség. ${ }^{41}$

39 Itt felvethető persze, hogy miként kerülhetne a munka törvénykönyvébe az internetes munkavégzés, ha nem igazán fér bele a munkaviszonyba. Ugyanakkor ez a kérdés az egyszerűsített foglalkoztatás és a bedolgozás tekintetében ugyanígy felmerül, amelyek viszont formálisan munkaviszonynak minősülnek.

40 A Taxify sofőrszabályzata a szabályszegéseket szankcionálja (sávos rendszerben). Kisebb problémák: talált tárgy, téves útvonal, etikátlan magatartás, fuvarelfogadások aránya, utastévesztés, öltözet, értékelés. Nagyobb problémák: a rendszer megkerülése, készpénz elfogadása, korai taxióraindítás/kései appleállítás, a gépjármű megfelelő állapota, POS-terminál/számla probléma, dohányzás, droszt, taxióra és az applikáció által mért fuvardíj, taxióra manipulálása, KRESZ, utaslopás, kompenzációs rendszer kijátszása.

41 Mt. 56. § (1) bekezdés. 
Polgári jogviszonyban a felek megállapodhatnak ilyen hátrányos jogkövetkezmények alkalmazásában. Polgári jogviszonyban nyilván elfogadhatjuk ilyen megállapodásnak azt is, ha a digitális platform felhasználási feltételeit, szabályzatát közlik az érintett munkavégzővel, és ő azt hallgatólagosan elfogadja. Nyilvánvalóan ennél megnyugtatóbb munkajogi megoldásra volna szükség az ilyen alapvető munkafeltételek szabályozása során, függetlenül a munkavégző munkajogi státuszától. Főleg annak fényében fontos ez, hogy a felhasználási feltételekből eredő egyik ilyen hátrányos jogkövetkezmény a jogviszony megszüntetése. A megszüntetéssel szemben így a munkáltató egyoldalú szabályzata alapján lényegében nincs semminemű védelme a munkavégzőnek.

A jogviszony megszüntetésével szembeni védelem olyan alapvető fontosságú kérdés, másként a munkajog ultima ratiója, amely ennél lényegesen körültekintőbb szabályozást és munkavállalói jogokat érdemelne. ${ }^{42}$ Fel kell hívni a figyelmet arra, hogy a jelenlegi szabályok és gyakorlat szerint a munkavégzőnek még ahhoz sincs joga, hogy vitassa a platformnak ezt a döntését. Ez viszont a jogorvoslat teljes hiányában foglalkoztatói visszaélésekre ad lehetőséget, és aláássa a foglalkoztatás és az állás biztonságát, amelyek viszont alapvető értékek a munkajogban.

További kérdés, hogy érvényesülnek-e a magyar jogban jelenleg az internetes munkavégzők vonatkozásában, tehát a munkaviszonyon kívül is az olyan univerzálisnak tekinthető jogok, mint a gyermekmunka tilalma és a diszkrimináció tilalma. A gyermekmunka tilalmára elvileg megnyugtató megoldást jelenthet az Mt. fiatal munkavállalókra vonatkozó szabálya, amely szerint a tizennyolcadik életévét be nem töltött személy nem munkaviszony keretében történő foglalkoztatására az Mt.nek a fiatal munkavállalóra vonatkozó rendelkezéseit kell megfelelően alkalmazni. ${ }^{43}$ Kérdéses viszont, hogy a jogviszony létesítésének korhatárára vonatkozó munkajogi szabályok ${ }^{44}$ alkalmazandók-e a tizennyolcadik életévét be nem töltött személy nem munkaviszony keretében történő foglalkoztatására, hiszen ezek nem minősülnek kifejezetten a fiatal munkavállalókra vonatkozó szabálynak. Kérdéses tehát az, hogy érvényesül-e a gyakorlatban a munkaviszonyon kívül a jogviszony létesítésének korlátozása 18 év alatti személyek esetében.

Az egyenlő bánásmódra vonatkozó szabályok esetében viszont sokkal egyértelműbb a helyzet. Az egyenlő bánásmódhoz való jogot részletesen rendező, 2003. évi CXXV. törvény ugyanis rendkívül tágan határozza meg a tárgyi hatályát. Ebböl következően az egyenlő bánásmód elvét alkalmazni kell mindennemü munkavégzésre, lényegében függetlenül a munkavégzésre irányuló jogviszony típusától. Így a diszkrimináció tilalma egyértelműen alkalmazandó a polgári jogviszonyokban, de lényegében minden más, munkavégzésre irányuló jogviszonytípusban is. ${ }^{45} \mathrm{Az}$ más kérdés, hogy a gyakorlatban egyáltalán nincsenek olyan ügyek, amelyekben polgári jogviszonyban sérelmezné a munkavégző az egyenlő bánásmód megsértését.

42 A jogviszony megszüntetésének munkajogi elméleti alapjairól részletesen lásd PETROvics Zoltán: $A$ biztonság árnyékában a munkajogviszony megszüntetésével szembeni védelem alapkérdései. PhD-értekezés, Budapest, 2016.

43 Mt. 4. §.

44 Mt. 34. § (2)-(3) bekezdés.

45 2003. évi CXXV. törvény 5. § d) pontja, valamint 3. § (1) bekezdés a)-b) pontjai. 
Így tehát halott jogról van szó, amelynek okait érdemes volna részletesebben megvizsgálni.

A kollektív jogok és különösen a kollektív szerződéskötés joga egyértelmüen a munkaviszonyhoz kötődnek ${ }^{46}$ így azon kívül lényegében alkalmazhatatlanok. A magyar munkaerőpiacon ráadásul a kollektív szerződés szinte kizárólag munkahelyi szinten létezik. Kollektív szerződést csak szakszervezet (szövetség) köthet, ha a munkáltatónál munkaviszonyban álló tagjainak száma eléri a munkavállalók létszámának tíz százalékát. ${ }^{47} \mathrm{Ez}$ tehát nyilvánvalóan nem lehetséges akkor, ha a munkavégzők nem munkavállalók. Alternatív lehetőségként kínálkozik az üzemi megállapodás mint kvázi kollektív szerződés megkötése. ${ }^{48}$ Ehhez viszont üzemi tanácsra volna szükség, amelynek megválasztására viszont megint csak a munkavállalók jogosultak. Ezzel az ördögi kör bezárulni látszik, hiszen a magyar munkajog - szinte minden más nemzeti munkajoghoz hasonlóan - a jogosultságok alapjának kizárólag a munkavállalói státuszt tekinti. ${ }^{49} \mathrm{~A}$ munkaviszonyon kívül tehát nem nagyon van magyar „munkajogi élet”, ebből eredően teljesen védtelen a munkavégző.

A megoldást nyilván nem a munkahelyi szintű kollektív szerződés megkötésében kellene keresni, hanem sokkal inkább az ágazati kollektív szerződés kiterjesztésében a munkaviszonyon túli jogviszonyokra, többek között az internetes munkavégzésre is. Ha volna például ágazati kollektív szerződés a személyszállításban, akkor annak vagy legalább egyes meghatározott rendelkezéseinek a hatályát kellene kiterjeszteni a taxis tevékenységet folytató digitális platformokra.

A problémát csak az jelenti, hogy jelen pillanatban - valószínűleg - nincsenek ${ }^{50}$ ágazati kollektív szerződések Magyarországon. A megoldást tehát abban kellene keresni, miként kellene elősegíteni ágazati kollektív szerződések megkötését, és hogyan lehet lehetővé tenni azok kiterjesztését a munkaviszonyon kívüli, bizonytalan foglalkoztatási formákra, közöttük a digitális platformoknak dolgozó internetes munkavégzőkre. Az ágazati párbeszéd bizottságokról és a középszintű szociális párbeszéd egyes kérdéseiről szóló 2009. évi LXXIV. törvény (Ápb. törvény) hatálya csak a munkavállalókra és az ő érdekképviseleteikre terjed ki. ${ }^{51}$

A munkaviszonyon kívüli jogviszonyok tekintetében tehát csak akkor ad lehetőséget az Ápb. törvény ágazati kollektív szerződés kötésére vagy a kollektív szerződés hatályának kiterjesztésére, ha a törvény módosul a hatály tekintetében. Az ágazati

46 Ez alól persze vannak kivételek, hiszen a szervezkedés szabadsága például értelemszerüen túlmutat a munkaviszonyon.

47 Mt. 276. § (1)-(2) bekezdés.

48 Mt. 268. §.

49 Doherty, Michael: Trade Unions and the Gig-Economy. In: Hendrickx, Frederic-De Stefano, Valerio: Game Changers in Labour Law. Shaping the Future of Work. (Bulletin of Comparative Industrial Relations, 2018/100), Wolters Kluwer, The Netherlands, Alphen aan den Rijn, 100.

50 Ez alól kivételt képez az egészségügy, amelyben 2017-ben született ágazati kollektív szerződés. https:// www.aeek.hu/-/kollektiv-szerzodes-az-egeszsegugyben-unnepelyes-alairas (2018. 10. 01.). A Munkaügyi Kapcsolatok Információs Rendszere (http://mkir.gov.hu/) tartja nyilván a kollektív szerződéseket, amely nyilvántartásból viszont nem állapítható meg jelenlegi állapotában, hogy mely kiterjesztett hatályú, ágazati kollektív szerződés van még valóban ma is hatályban. Éppen ezért nem lehet pontosan nyilatkozni arról sem, hogy valójában van-e hatályban ágazati kollektív szerződés ma Magyarországon, amely tény jól jellemzi a helyzetet.

51 Ápb. törvény 1-2. §, 15. § (1) bekezdés. 
kollektív szerződés alkalmazását indokoltnak tartom a munkaviszonyon kívüli jogviszonyokra is. Ugyanakkor ennek az az alapvető feltétele, hogy az ilyen, elsődlegesen polgári jogviszonyban dolgozók érdekképviseletei ${ }^{52}$ is részt vegyenek az ágazati kollektív szerződés kidolgozásában és elfogadásában. ${ }^{53}$

Éppen ezért lesz fontos az, hogy a magyar haknigazdaság kezdeteinél is ott legyenek a hagyományos szakszervezetek, illetve alakuljanak ki a haknigazdaságban dolgozók érdekképviseletei. Ez ugyanis az alapvető feltétele annak, hogy ne kerüljenek rögtön behozhatatlan hátrányba a kollektív jogaikkal, így különösen a kollektív alku jogával kapcsolatosan.

A magyar munkajog tehát csak töredékesen biztosítja ma a munkaviszonyon kívül, más jogviszonyban, például interneten keresztül munkát végzőknek a fenti jogokat. A diszkrimináció tilalma valóban megnyugtató módon szabályozott, megfelelően széles tárgyi hatállyal, bár a gyakorlatra nincs érdemi hatása. Ugyanakkor az online értékelés, a fegyelmi felelősség korlátai, a jogviszony megszüntetésével szembeni védelem, a kollektív jogok és a gyermekmunka tilalma ma sem a jogszabályokban, sem a gyakorlatban nem érvényesülnek. Természetesen ez nem a teljes katalógus, amely jogokat érdemes és szükséges biztosítani az interneten keresztül dolgozók számára, hanem csak példálózó elemzés néhány lényeges jogról. Véleményem szerint indokolt volna kifejezetten az interneten keresztül munkát végzők számára külön, részletes szabályozásban biztosítani az alapvető munkavállalói jogokat, beleértve a fentiekben elemzett jogosultságokat. Ez történhet munkaviszonyként, az Mt. eltérő szabályaival vagy önálló jogviszonyban, külön törvényben. Nem a szabályozás formája a fontos, hanem a tartalom, vagyis a munkavégzőt megillető jogok katalógusa és azoknak a gyakorlatban alkalmazható és valóban érvényesülő részletszabályai.

\section{5. Összegzés: a részletes szabályozás a megoldás}

Az interneten keresztül történő munkavégzés egy meglehetősen új és egyben újszerü munkavégzési forma mind Magyarországon, mind pedig szerte a világon. A nem szokványos, másként bizonytalan munkavégzési formák tömeges megjelenése az elmúlt évtized meghatározó munkajogi tendenciája a fejlett országokban. A nem szokványos munkavégzési formák között viszont kétségtelenül a legújabb az interneten keresztül történő munkavégzés. Ez a munkavégzési forma mintegy bő egy évtizedes múltra tekint vissza, hiszen elnevezése is 2006-ban született, jellemző módon John Howe internetről szóló internetes blogbejegyzésében. Nem is lehet hosszabb története, hiszen az ilyen munka alapfeltétele az internet megléte és annak széles körű használata, elterjedése.

52 Ennek természetesen vannak versenyjogi összefüggései és akadályai, amelyek komoly vitákat váltottak ki például az Európai Bíróság előtt. Lásd például C-413/13 FNV Kunsten Informatie en Media v Staat der Nederlanden ügy [2014] ECLI:EU:C:2014:2411.

53 A szerző köszönettel tartozik Kártyás Gábornak a fenti javaslatért, illetve az ágazati kollektív szerződésekkel kapcsolatos véleményéért. 
Az interneten keresztül történő munkavégzés nem pusztán egy új, hanem egyben újszerü forma is, hiszen az internet használata lehetővé teszi ismeretlen nagyságú munkavégző tömeg foglalkoztatását, valamint a megrendelői, fogyasztói igényekhez való rendkívül gyors alkalmazkodást. Az internetes munkavégzés gyűjtőfogalom, amely rendkívül heterogén munkavégzési formákat foglal magába, de két fő típusa a crowdsourcing és az applikáción keresztül történő munkavégzés.

A magyar jogalkotás más nemzeti munkajogokhoz hasonlóan komoly dilemma előtt áll. A kérdés az, miként lehet beilleszteni ezt a Magyarországon még alig létező, de minden bizonnyal itt is hamarosan tömegesen elterjedő munkavégzési formát a hagyományos magyar munkajogi paradigmába. A munkaviszonyba nehezen férne bele ez a forma, de a munkajogi szabályok nem is alkalmazhatók mechanikusan az ilyen munkavégzőkre. Továbbá számos speciális szabály hiányzik is, amelyek a klasszikus munkaviszonynál nem voltak szükségesek. Az önfoglalkoztatás nyilván nem megoldás, hiszen lényegében minden védelemtől megfosztja a munkavégzőt.

Véleményem szerint részben vagy egészben különálló, speciális szabályozásra volna szükség. ${ }^{54} A$ szabályozás tartalmához képest másodlagosnak ítélem azt a népszerü kérdést, hogy munkaviszonynak nevezzük az internetes munkavégzők jogviszonyát. A 2012. évi Mt. stratégiája az volt, hogy szinte minden, eddig az Mt.-n kívüli jogviszonyt bevont - formálisan atipikus munkaviszonyként - az Mt. hatálya alá. Ebből eredően logikus folytatásnak tűnik, hogy az internetes munkavégzést is formálisan atipikus munkaviszonynak tekintsük, természetesen az Mt. általános szabályaitól számos kérdésben (például megszüntetés, munkaidő, kollektív jogok) eltérő szabályokkal. Ugyanakkor más formai megoldás is elképzelhető, de a szabályozás tartalma az elsődleges kérdés, amelyre igyekeztem korábban számos javaslatot és szabályozási elvet, szempontot azonosítani. Érdemes volna tehát előre gondolkodni, és nem megvárni, amíg a probléma eléri azt a mértéket, amikor már muszáj beavatkozni.

\section{Abstract}

Working through digital platforms and apps is a new and rare form of work in Hungary. The spread of digital work is quite new all over the world and also part of the wider trend of precarious forms of work. Hungarian labour law faces serious challenges regarding crowdsourcing and working via apps. The main question is how to insert these new forms of work into the existing labour law framework. These new forms may hardly be considered as employment relationships due to the serious differences. Self-employment cannot be the solution either, since it would leave workers without any employment protection. Therefore, regulation of digital work is unavoidable, even if its details are far from clear for the moment.

54 Ezzel szemben Kovács Erika ezt a külön státuszt csak végső megoldásnak tekinti, ha a már létező munkajogi kategóriákkal semmiképpen sem lehet kezelni az internetes munkavégzést. Álláspontja szerint ugyanis egy ilyen új, különálló munkajogi státusz csak még bonyolultabbá tenné a munkavégzésre irányuló jogviszonyok rendszerét. Kovács: i. m., 9. 